\title{
The role of mesenchymal stem cells in COVID-19 treatment
}

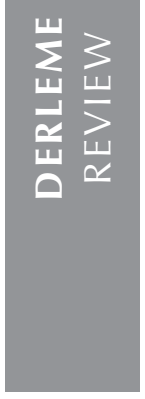

Cite this article as: YIldız Gülhan P. The role of mesenchymal stem cells in COVID-19 treatment. Tuberk Toraks 2020;68(4):430-436.

\section{Yazışma Adresi (Address for Correspondence)}

\section{Dr. Pınar YILDIZ GÜLHAN}

Düzce Üniversitesi Tıp Fakültesi, Göğüs Hastalıkları Anabilim Dalı, DÜZCE - TÜRKIYE

e-mail: pinaryildiz691@hotmail.com

(C) Copyright 2020 by Tuberculosis and Thorax. Available on-line at www.tuberktoraks.org.com
${ }^{1}$ Department of Chest Diseases, Düzce University Faculty of Medicine, Düzce, Turkey

${ }^{1}$ Düzce Üniversitesi Tıp Fakültesi, Göğüs Hastalıkları Anabilim Dalı, Düzce, Türkiye

\begin{abstract}
The role of mesenchymal stem cells in COVID-19 treatment

The novel coronavirus (SARS-CoV-2) pandemic has created a sense of global panic and the medical community started to search for rapid answers. Pharmaceuticals and research labs across the world are racing to find vaccines and treatments for the new coronavirus, using a variety of different technological ways. With Coronavirus disease (COVID-19), it is observed that asymptomatic symptoms turn out to be severe and fatal. By raising pyrexia, sepsis, acute respiratory distress syndrome (ARDS), and multiple organ failure are observed to develop which are not only associated with coronavirus. The treatment of the virus and the systemic inflammatory response it causes are also very important. The rapid response to infection has been well defined and comprises a complex interaction of cytokine storm, endothelial dysfunction, inflammation, and pathologic coagulation. Since the effective therapies are missing and immunological treatments may be deficient, mesenchymal stem cells (MSCs), by reason of their potent immunomodulatory ability, can have useful results in order to prevent the cytokine storm and reduce morbidity and mortality for COVID-19. The aim of this article is to discuss the potential effect of MSCs types in COVID-19 infection without definite treatment.
\end{abstract}

Key words: COVID-19; mesenchymal stem cells; pandemic; SARS-CoV-2

ÖZ

\section{COVID-19 tedavisinde mezenkimal kök hücrelerin rolï}

Yeni koronavirüs (SARS-CoV-2) salgını küresel bir sorun yarattı ve tıp dünyası hastalık için hızlı cevaplar aramaya başladı. Dünyanın dört bir yanındaki ilaç ve araştırma laboratuvarları, çeşitli farklı teknolojik yollar kullanarak yeni koronavirüs için aşılar ve tedaviler bulmak için çabalamaktadır. Coronavirüs hastaIığı (COVID-19) ile asemptomatik durumdan şiddetli semptomatik durumlara ve ölüme neden olabilmektedir. Sadece virüs enfeksiyonu ile ilişkili olmayan; sepsis, akut solunum sıkıntısı sendromu (ARDS) ve çoklu organ yetmezliğinin geliştiği gözlenir. Virüsün tedavisi ile birlikte neden olduğu sistemik inflamatuar yanıtın tedavisi de çok önemlidir. Vücudun enfesiyona verdiği hızlı yanıt iyi tanımlanmıştır ve sitokin fırtınası, endotel disfonksiyonu, inflamasyon ve pato- 
lojik pıhtılaşma arasında karmaşık bir etkileşim içerir. Etkili terapiler eksik olduğundan ve immünolojik tedaviler yetersiz olabileceğinden, mezenkimal kök hücreler (MKH'ler), güçlü immünomodülatör yetenekleri nedeniyle, sitokin fırtınasını önlemek ve COVID-19'da morbidite ve mortaliteyi azaltmak için faydalı sonuçlara sahip olabilir. Bu makalenin amacı kesin tedavisi olmayan COVID-19 enfeksiyonunda MKH'in potansiyel etkilerini gözden geçirmektir.

Anahtar kelimeler: COVID-19; mezenkimal kök hücreler; pandemi; SARS-CoV-2

\section{INTRODUCTION}

The novel coronavirus (SARS-CoV-2) is defined to be enveloped, positive-sense single-stranded RNA viruses with a nucleocapsid of helical symmetry. Coronaviruses belong to "Coronavirinae" (family; Coronaviridae, order; Nidovirales) that has four genera. The names of these groups are alpha-coronavirus, beta-coronavirus, gamma coronavirus and delta-coronavirus. Gamma and delta coronaviruses generally infect birds. However, some of them may cause infection in mammals. It was known that alpha and beta coronaviruses are harmful for humans and animals. It was shown before that the SARS-CoV; $229 \mathrm{E}$ (alpha coronavirus), HKU1 (beta coronavirus), NL63 (alpha coronavirus), OC43 (beta coronavirus) and MERS-CoV (beta coronavirus) can cause infectiousness in humans. At the same time, beta coronaviruses contain the high pathogenic viruses in humans including SARS-CoV-2, MERS-CoV and SARS-CoV (1).

The 2019-nCoV causes an ongoing the pandemic disease named novel coronavirus pneumonia by the Chinese government. World Health Organization recommended the name Coronavirus disease (COVID-19) for this disease. International Committee on Taxonomy of Viruses renamed the disease as SARS-CoV-2 (2).

In Wuhan, Hubei Province, China a disease was determined with pneumonia of unknown cause in December 2019. At first, it was linked with a seafood market. The local hospitals identified the virus, (SARS-CoV-2. They used a surveillance mechanism for "pneumonia of unknown aetiology" that was founded in 2003 during the SARS outbreak. World Health Organization (WHO) declared "public health emergency of international concern" for COVID-19 in 30 January 2020. The pandemic spread rapidly (3).

It was early to speak about fatality rates but China reported the fatality rate, less than $4 \%$. This rate seems low when compared with SARS-CoV and MERS-CoV (10\% and $37 \%$, respectively) (4).
Looking at the coexistence of symptoms; the majority of patients had a fever with cough; had a fever with dyspnea; had a fever with fatigue, myalgia or headache (5).

These results show that risk factors can be associated with age and comorbidities for critical patients. The pathogenesis of COVID-19 are mostly related to cardiovascular diseases such as hypertension, diabetes, respiratory system disease, cardiovascular diseases (6).

For COVID-19 patients developing acute respiratory distress syndrome (ARDS) requiring intubation and mechanical ventilation, shock and multiple organ failure may also develop whereas it is obvious whether this is a direct result of viral infection or critical disease complications are not yet clear. The most current therapeutic approaches contain aggressive standard supportive care and treatment of other co-infections. Anti-viral drugs, including remdesivir, lopinavir-ritonavir or lopinavir-ritonavir, and interferon beta-1, are being researched. However, safety and potential efficacy have not yet been provided. Remdesivir and interferon-beta seem to have superior antiviral activity against lopinavir and remdesivir in vitro for MERS coronavirus. Nevertheless, it is still uncertain whether this is valid for SARS-CoV-2 (7).

The use of hydroxychloroquine in COVID-19 patients has been confirmed by the FDA lately., but efficacy has not been established. Additionally, increasing information shows that virus-induced cytokine storm in the lungs is important in the pathogenesis and can bring potential therapeutic targets, for example, antiIL6 or anti-IL-1 approaches $(8,9)$. Persistence of cytokine storm will possibly be one of the main cause of severe organ injury and death (10).

MSCs are adult multipotent progenitor cells existing in connective tissues such as bone marrow, adipose tissue, synovium, placenta, and umbilical cord. A plethora of paracrine soluble factors including angiopoietin, keratinocyte growth factor, prostaglandin E2, interleukin-10 (IL-10) and other trophic cytokines are secreted by MSCs. These paracrine factors can esca- 
lade alveolar fluid clearance, balance lung epithelial and endothelial permeability, facilitate endothelial regeneration and decrease inflammation. MSCs attract particular of attention due to their broad pharmacological effects, including anti-inflammatory, immunomodulatory, regenerative, pro-angiogenic and anti-fibrotic properties (11-14).

Because of these properties, they are candidates for using in the treatment of COVID-19 pneumonia infection, which causes cytokine storm and ARDS.

The first coronavirus case treated with MSCs was reported by Liang B et al. A 65 years old woman patient who has severe pneumonia, respiratory failure and multiorgan failure needing mechanical ventilation was hospitalised. She was treated with three doses each of $50 \times 10^{6}$ allogeneic umbilical cord stem cells, three days apart. Two days later the third infusion, she was taken out of the ICU to the regular ward since she showed recovery with most of her laboratory indexes getting normal level (15).

In a study reported by Leng et al. (16), 7 patients with COVID-19 pneumonia were treated with MSCs in an intravenous way. They developed functional outcomes and improved recovery after an intravenous administration of clinical-grade human MSCs. The patients were positive SARS-CoV-2 was positive in these patients, with one having a critically severe type, four being observed severe types, and the other two showing common types of the syndrome. Additionally, three patients with severe types were taken care for placebo control. Before MSCs infusion, all patients displayed, short breathing, high fever, low oxygen saturation and pneumonia. The patients were treated with $1 \times 10^{6}$ MSCs per kilogram body weight. Especially, the study indicated that basically all symptoms lessened by 2-4 days after receiving MSCs infusion. Also, no adverse effects, over a week or two after MSCs infusion, were observed and the majority of patients showed negative results for the SARSCoV-2 nucleic acid test. The improvement that an elderly patient showed was quite outstanding for in a critical condition after the infection. After a study; the investigators compared seven patients (one critically serious, four serious and two commons) infected with the coronavirus who was treated with one dose of stem cell therapy with 3 patients in the control group who did receive standard treatment procedure. They were followed for two weeks. All seven patients with stem cell therapy were successful. However, in the control group, one patient died while another patient developed ARDS. Only one patient in the control group was stable. Any complications weren't noted in the treatment group. In the treated group, biomarkers for inflammation like C-Reactive protein, the oxygen saturation aspartic aminotransferase, creatine kinase activity and myoglobin were normal levels (Table 1) (16).

These results suggest that immunological therapy used to treat infected patients. Because the immunomodulatory capacity could not be strong enough. As a result of this; the virus can stimulate a damaging cytokine storm in the lung, such as IL-1, IL-6, GSCF, MCP1, MIP1A, IP10 and TNF $\alpha$, followed by the oedema, dysfunction of the air exchange, acute respiratory distress syndrome, acute cardiac injury and the secondary infection. These are can cause death. Therefore, the decrease of cytokine storm may be an important point for the treatment of COVID-19 infected patients. MSCs, due to their powerful immunomodulatory ability, may have useful effects to prevent or attenuate the cytokine storm $(4,16)$.

MSCs, by the release of soluble factors, can show their effect via cell contact-dependent mechanisms. The mechanisms of alveolar damage during ARDS and factors providing lung regeneration produced by MSCs (17).

Table 1. Two studies reporting mesenchymal stem cell activity in the treatment of COVID-19

\begin{tabular}{|c|c|c|c|c|c|c|c|}
\hline References & Cell type & Dose & $\begin{array}{c}\text { No } \\
\text { patient }\end{array}$ & Decrease & $\begin{array}{c}\text { Administered } \\
\text { way }\end{array}$ & Increases & Hospital \\
\hline Bing Liang (15) & $\begin{array}{l}\text { Umblical } \\
\text { cord }\end{array}$ & $\begin{array}{l}\text { three times } \\
\left(5 \times 10^{7} \text { cells }\right. \\
\text { each time })\end{array}$ & 1 & Crp & Intravenous & $\begin{array}{c}\mathrm{CD} 3+\mathrm{T} \\
\mathrm{CD} 4+\mathrm{T} \\
\mathrm{CD} 8+\mathrm{T} \\
\text { lenosit }\end{array}$ & $\begin{array}{l}\text { Baoshan } \\
\text { People's } \\
\text { Hospital }\end{array}$ \\
\hline Zikuan Leng et al. (16) & $\begin{array}{l}\text { Umblical } \\
\text { cord (34) }\end{array}$ & $\begin{array}{l}1 \times 10^{6} \\
\text { cells per } \\
\text { kilogram }\end{array}$ & 7 & TNF- $\alpha$ & Intravenous & $\begin{array}{c}\text { IL-10, VEGF, } \\
\text { IP-10 }\end{array}$ & $\begin{array}{c}\text { Beijing YouAn } \\
\text { Hospital }\end{array}$ \\
\hline
\end{tabular}




\section{Bone Marrow-Derived Mesenchymal Stem Cells (BM-MSCs)}

MSCs; originate from bone marrow, umbilical cord fat, placenta, and other tissues. MSCs have a strong differentiation potential, potent immunoregulation and endogenous repairability.

Allogeneic bone marrow-derived human mesenchymal stem (stromal) cells (BM-MSCs) therapy is alluring as a highly effective treatment for ARDS for various grounds. MSCs are multipotent cells with low immunogenicity that secrete multiple paracrine factors including endothelial and epithelial growth factors, anti-inflammatory cytokines, antifibrotic and antimicrobial peptides. Same time; they also have potency in transferring mitochondria to injured epithelial cells (18).

\section{Umbilical Cord Mesenchymal Stem Cells (UC-MSCs)}

Among which, the umbilical cord mesenchymal stem cells (UC-MSCs) can easily get and cultured. UC-MSCs have shown quite crucial immunomodulation and tissue fixing effects with low immunogenicity. This capacity makes them very ideal aspirants to the allogeneic adoptive transfer therapy. It was further pointed out to be promising to medicate the $\mathrm{H} 5 \mathrm{~N} 1$ infection-induced acute lung injury, which indicated related inflammatory cytokine profile to that of COVID-19 (15,19).

\section{Adipose-derived Stromal Stem Cells (ASCs)}

Adult human adipose tissue originates from embryonic mesoderm and represents more and less invasive mesenchymal stem cell sources than bone marrow (20).

Human Adipose-derived Stromal Stem Cells (ASCs) are an attractive cell source for generating other cells because these cells can secrete multiple growth factors and cytokines that exert beneficial effects on organ or injured tissue (21).

Zuk et al defined Adipose-derived MSCs (AD-MSCs) in human fat tissue by (22). This caused the acceptance of adipose tissue as an alternative to BM for MSCs in 2001. BM-MSCs exist in the bone marrow stroma in moderately small amounts. It has been estimated that they comprise about $0.001-0.01 \%$ of the total marrow nucleated cells. But the proportion of adipose-derived MSCs is about $2 \%$ of all nucleated cells of adipose tissue. Thus; caused MSCs from adi- pose tissue to make them more suitable for MSC treatment and clinical applications $(23,24)$.

AD-MSCs have separate benefits as compared to BM-MSCs. It has been originally proven that both BM-MSCs and AD-MSCs exhibit immunosuppressive means in vitro studies. AD-MSCs can be more potent suppressors of the immune response. They were undoubtedly far better than BM-MSCs in inhibiting both the differentiation of blood monocytes into dendritic cells as identified by CD83 expression and the expression of co-stimulatory molecules (CD80, CD86) on the surface of mature monocyte-derived dendritic cells. Adipose-originated MSCs were firmer than BM-MSCs at stimulating the secretion of immunosuppressive IL-10 cytokine by dendritic cells (2528).

\section{Mesenchymal Stromal Cell Secretome (MSC-secretome)}

MSC-secretome consists of both soluble proteins, containing a broad range of cytokines, chemokines and growth factors and extracellular vesicles (EVs) of micro- and nano-size (29).

As soon as they are set free, EVs and soluble proteins interact with the target cells (by ligand-receptor interaction or by internalization) and regulate cellular responses. Secretome can trigger endogenous stem cells and progenitor cells, moderate the inflammatory response, decrease apoptosis, promote the remodelling of the extracellular matrix, angiogenesis and lower fibrosis and mediate the chemoattraction (30).

Human MSC-derived EVs have been shown to reduce lung permeability and edema in a murine model of LPS-induced acute lung injury. They are also reduced macrophage inflammatory protein-2 levels and neutrophil infiltration in bronchoalveolar lavage fluid (BALF) (31).

Especially, the employment of secretome in therapy has got a number of advantages compared to MSCs. Secretome is widely regarded as safer than cells: it requires the efficiency for endogenous tumour formation since it cannot self-replicate, it has poor immunogenicity and when intravenously injected it causes to fewer emboli formation (32).

The use of MSC-secretome in therapy also necessitates technological benefits: it can be directed and stored easier than cells, with fewer costs and it fol- 
lows a ready to use product suitable for emerge interventions $(11,12)$.

\section{Clinical Trials Perspective}

In consideration of the therapeutic potential of MSCs, several firms have started the process to test adult-tissue MSCS products. These products were already in clinical testings for other conditions to observe if they might be beneficial in solving inflammatory COVID19 respiratory conditions.

Obviously, there is considerable attention in exploring stem cells, comprising ASCs, as a strong therapeutic option in COVID-19 respiratory conditions. It is appropriate to point out that the clinical results, early reported, must be restated in larger, well-controlled testings to completely see if the approach is safe and beneficial. At present, 30 clinical trials have been registered (https://clinicaltrials.gov) to assess the MSCs as clinical treatment of patients affected by COVID19. (https://clinicaltrials.gov/ct2/results?term=Mesenchymal+Stem+Cells\&cond=COVID-19\&draw=3.) Of these clinical trials, in particular, two are on dental pulp stem cells, ten are on umbilical cord stem cells, one is on mesenchymal stromal cells, one on mesenchymal stem cells-exosomes, and two are on adipose-derived mesenchymal stem cells.

For 7 years, clinical trials benefit from MSCS from variable sources [bone marrow (BM), fat, and umbilical cord $(U C)]$ in the treatment of ARDS. Some clinical trials are being carried out and the final reports are not announced. In all final reports, the safety of the application of MSCS has been reported and most of them indicated progress in mortality and decrease of morbidity.

\section{Which are the Best Safety Stem Cells to Treat Coronavirus?}

Studies will show which type of MSCs cells which type and which route of administration (intratracheal, intravenous) will be safer and more effective in COVID-19 infection. But; According to the theoretical information we know; umbilical cord has a high concentration of stem cells (33).

During the past ten years, umbilical cord blood has been considered to be therapeutically beneficial for relieving patients with bone marrow-related deficits and inborn errors of metabolism. Umbilical cord blood presents superiority over bone marrow. Cord blood can be used allegorically as the excellent human leukocyte antigen (HLA) does not require tissue matching and has a low graft incidence against host disease (34).

UC-MSCs can be extracted noninvasively. There is no procedure. Invasive procedures are required in bone marrow or fat stem cells. Since COVID-19 infection can cause a systemic and widespread disease; Millions of stem cells may need to be injected for clinical efficacy (35).

In patients diagnosed with COVID-19, increased inflammation, hypoxemia, immobilization and increased intravascular coagulation can cause thrombosis in both arterial and venous systems. Therefore, procedures that are least thrombogenic should be preferred when planning stem cell therapy (36). EVs should be kept in mind due to their lower thrombogenic effect.

Jung, et al. reported a pulmonary embolism in a family (mother, father, and children) who received ASCs treatment due to knee osteartritis and stated that they reported these as the first case. Considering that COVID-19 infection causes damage to the endothelium and causes predisposition to thrombosis, we think that it should be used with caution (37).

There are studies showing that the tissue factor is highly expressed and localized on the cell surface of cultured ASC and that the tissue factor is a trigger factor in the coagulation pathway activated by the infused ASC $(37,38)$.

To mitigate acute respiratory disease and pulmonary fibrosis in intensive-care SARS-CoV-2-infected patients, there are three curative functions of MSCs have arisen. 1: Directly promoting the apoptosis of activated $T$ cells to ease the aberrant and extra immune responses. 2: Injuries of the lung to maintain homeostasis as well as promote regeneration 3: Delivering cytokines for decrease inflammation (39).

Throughout the pandemic threat of SARS-CoV-2 to global health and the fast-growing number of fatalities, advancing new therapeutic development becomes central or primary to minimize the death and sequelae from SARS-CoV-2 infection. Therefore MSCs treatment should be considered as a potential treatment for these critical patients. 


\section{REFERENCES}

1. Khan S, Siddique R, Shereen MA, Ali A, Liu J, Bai Q, et al. emergence of a novel coronavirus, severe acute respiratory syndrome coronavirus 2: Biology and therapeutic options. J Clin Microbiol 2020; 58: e00187-20.

2. Yuen KS, Ye ZW, Fung SY, Chan CP, Jin DY. SARS-CoV-2 and COVID-19: The most important research questions. Cell Biosci 2020; 10: 40.

3. Wu D, Wu T, Liu $Q$, Yang Z. The SARS-CoV-2 outbreak: What we know. Int J Infect Dis 2020; 94: 44-8.

4. Huang C, Wang Y, Li X, Ren L, Zhao J, Hu Y, et al. Clinical features of patients infected with 2019 novel coronavirus in Wuhan, China. Lancet 2020; 395: 497-506.

5. Wu C, Chen X, Cai Y, Xia J, Zhou X, Xu S, et al. Risk factors associated with acute respiratory distress syndrome and death in patients with coronavirus disease 2019 pneumonia in Wuhan, China. JAMA Intern Med 2020: e200994.

6. Guan WJ, Ni ZY, Hu Y, Liang WH, Ou CQ, He JX, et al. Clinical characteristics of coronavirus disease 2019 in China. N Engl J Med 2020; 382: 1708-20.

7. Sheahan TP, Sims AC, Leist SR, Schäfer A, Won J, Brown AJ, et al. Comparative therapeutic efficacy of remdesivir and combination lopinavir, ritonavir, and interferon beta against MERS-CoV. Nat Commun 2020; 11: 222.

8. Mehta P, McAuley DF, Brown M, Sanchez E, Tattersall RS, Manson JJ, et al. COVID-19: consider cytokine storm syndromes and immunosuppression. Lancet 2020; 395: 1033-4.

9. Khoury M, Cuenca J, Cruz FF, Figueroa FE, Rocco PRM, Weiss DJ. Current status of cell-based therapies for respiratory virus infections: applicability to COVID-19. Eur Respir J 2020; 55: 2000858.

10. Xu Z, Shi L, Wang Y, Zhang J, Huang L, Zhang C, et al. Pathological findings of COVID-19 associated with acute respiratory distress syndrome. Lancet Respir Med 2020; 8: 420-2.

11. Bari E, Ferrarotti I, Torre ML, Corsico AG, Perteghella S. Mesenchymal stem/stromal cell secretome for lung regeneration: The long way through "pharmaceuticalization" for the best formulation. I Control Release 2019; 309: 11-24.

12. Bari E, Ferrarotti I, Saracino L, Perteghella S, Torre ML, Corsico AG. Mesenchymal stromal cell secretome for severe COVID-19 infections: premises for the therapeutic use. Cells 2020; 9: 924.

13. Ortiz LA, Dutreil M, Fattman C, Pandey AC, Torres G, Go $K$, et al. Interleukin 1 receptor antagonist mediates the antiinflammatory and antifibrotic effect of mesenchymal stem cells during lung injury. Version 2. Proc Natl Acad Sci (USA) 2007; 104: 11002-7.

14. Keating A. Mesenchymal stromal cells: new directions. Cell Stem Cell 2012; 10: 709-16.
15. Liang B, Chen J, Li T, Wu H, Yang $W, L i Y$, et al. Clinical remission of a critically ill COVID-19 patient treated by human umbilical cord mesenchymal stem cells. ChinaXiv 2020; 202002.00084.

16. Leng $Z$, Zhu $R$, Hou $W$, Feng $Y$, Yang $Y$, Han $Q$, et al. Transplantation of ACE2- mesenchymal stem cells improves the outcome of patients with COVID-19 pneumonia. Aging Dis 2020; 11: 216-28.

17. Cruz T, Rojas M. Preclinical Evidence for the Role of Stem/ Stromal Cells in Targeting ARDS. Burgess JK, Irene H (eds). Heijink. In: Stem cell-based therapy for lung disease. Springer Nature Switzerland AG 2019, 199-219.

18. Wilson JG, Liu KD, Zhuo H, Caballero L, McMillan M, Fang $X$, et al. Mesenchymal stem (stromal) cells for treatment of ARDS: a phase 1 clinical trial. Lancet Respir Med 2015; 3: 24-32.

19. Darwish I, Mubareka S, Liles WC. Immunomodulatory therapy for severe influenza. Expert Rev Anti Infect Ther 2011; 9: 807-22.

20. Shen JF, Sugawara A, Yamashita J, Ogura H, Sato S. Dedifferentiated fat cells: an alternative source of adult multipotent cells from the adipose tissues. Int J Oral Sci 2011; 3: 117-24.

21. Sensebé L, Bourin P. Mesenchymal stem cells for therapeutic purposes. Transplantation 2009; 87: 49-53.

22. Zuk PA, Zhu M, Mizuno H, Huang J, Futrell JW, Katz AJ, et al. Multilineage cells from human adipose tissue: implications for cell-based therapies. Tissue Eng 2001; 7: 211-28.

23. Bernardo ME, Locatelli F, Fibbe WE. Mesenchymal stromal cells. Ann N Y Acad Sci 2009; 1176: 101-17.

24. Qayyum AA, Haack-Sørensen M, Mathiasen AB, Jørgensen E, Ekblond A, Kastrup J. Adipose-derived mesenchymal stromal cells for chronic myocardial ischemia (MyStromalCell Trial): study design. Regen Med 2012; 7: 421-8.

25. Yañez $R$, Lamana ML, García-Castro J, Colmenero I, Ramírez M, Bueren JA. Adipose tissue-derived mesenchymal stem cells have in vivo immunosuppressive properties applicable for the control of the graft-versus-host disease. Stem Cells 2006; 24: 2582-91.

26. Ivanova-Todorova E, Bochev I, Mourdjeva M, Dimitrov $R$, Bukarev D, Kyurkchiev $S$ et al. Adipose tissue-derived mesenchymal stem cells are more potent suppressors of dendritic cells differentiation compared to bone marrow-derived mesenchymal stem cells. Immunol Lett 2009; 126: $37-42$.

27. Zheng G, Huang L, Tong $H$, Shu $Q, H u Y$, Ge $M$, et al. Treatment of acute respiratory distress syndrome with allogeneic adipose-derived mesenchymal stem cells: a randomized, placebo-controlled pilot study. Respir Res 2014; 15: 39.

28. Gentile P, Sterodimas A. Adipose-derived stromal stem cells (ASCS) as a new regenerative immediate therapy combating coronavirus (COVID-19)- induced pneumonia. Expert Opin Biol Ther 2020: 1-6. 
29. Crivelli B, Chlapanidas T, Perteghella S, Lucarelli E, Pascucci L, Brini AT, et al. Mesenchymal stem/stromal cell extracellular vesicles: From active principle to next generation drug delivery system. I Control Release 2017; 262: 104-17.

30. Kyurkchiev D, Bochev I, Ivanova-Todorova E, Mourdjeva $M$, Oreshkova T, Belemezova K, et al. Secretion of immunoregulatory cytokines by mesenchymal stem cells. World J Stem Cells 2014; 6: 552-70.

31. Zhu YG, Feng XM, Abbott J, Fang XH, Hao $Q$, Monsel $A$, et al. Human mesenchymal stem cell microvesicles for treatment of Escherichia coli endotoxin-induced acute lung injury in mice. Stem Cells 2014; 32: 116-25.

32. Zhu X, Badawi M, Pomeroy S, Sutaria DS, Xie Z, Baek A, et al. Comprehensive toxicity and immunogenicity studies reveal minimal effects in mice following sustained dosing of extracellular vesicles derived from HEK293T cells. I Extracell Vesicles 2017; 6: 1324730.

33. Arutyunyan I, Elchaninov A, Makarov A, Fatkhudinov T. Umbilical cord as prospective source for mesenchymal stem cell-based therapy. Stem Cells Int 2016; 2016: 6901286.

34. Weiss ML, Troyer DL. Stem cells in the umbilical cord. Stem Cell Rev 2006; 2: 155-62.
35. Atluri S, Manchikanti L, Hirsch JA. Expanded umbilical cord mesenchymal stem cells (UC-MSCS) as a therapeutic strategy in managing critically III COVID-19 patients: the case for compassionate use. Pain Physician 2020; 23 : E71-E83.

36. Klok FA, Kruip MJHA, van der Meer NJM, Arbous MS, Gommers DAMPJ, Kant KM et al. Incidence of thrombotic complications in critically ill ICU patients with COVID-19. Thromb Res 2020; 191: 145-7.

37. Jung JW, Kwon M, Choi JC, Shin JW, Park IW, Choi BW, et al. Familial occurrence of pulmonary embolism after intravenous, adipose tissue-derived stem cell therapy. Yonsei Med J 2013; 54: 1293-6.

38. Tatsumi K, Ohashi K, Matsubara Y, Kohori A, Ohno T, Kakidachi $\mathrm{H}$, et al. Tissue factor triggers procoagulation in transplanted mesenchymal stem cells leading to thromboembolism. Biochem Biophys Res Commun 2013; 431: 203-9.

39. Ji F, Li L, Li Z, Jin Y, Liu W. Mesenchymal stem cells as a potential treatment for critically ill patients with coronavirus disease 2019. Stem Cells Transl Med 2020: 10.1002/ sctm.20-0083. 